\title{
LEARNING MANAGEMENT SYSTEMS: ENGINEERING THE EDUCATION INDUSTRY TO EDUCATE THE INDUSTRIAL ENGINEER
}

\author{
L. van Dyk \\ Department of Industrial and Systems Engineering \\ University of Pretoria \\ 1vdyk@up.ac.za
}

\begin{abstract}
A learning management system (LMS) is any infrastructure on which e-learning can be built and delivered. In this article two sides of the LMS coin are investigated: On the one side, it is argued that industrial and systems engineering skills are equally relevant for learning systems as for as for any other system. To support this argument, an analogy is drawn between the management of learning systems and the management of manufacturing systems. On the other side of the coin, the educational issues and concerns related to implementing an LMS at the University of Pretoria are investigated by means of a case study in the Industrial Engineering department. It is concluded that the industrial engineering educator is in the unique position of understanding and contributing towards the engineering of the education industry whilst educating the industrial engineer.
\end{abstract}

\section{OPSOMMING}

' $n$ Leerbestuurstelsel (LMS) is enige infrastruktuur waarop e-leer gebou en afgelewer kan word. In hierdie artikel word beide kante van die LMS muntstuk ondersoek: Aan die een kant word getoon dat bedryfsingenieursvaardighede en -beginsels ewe toepaslik is op leerstelsels as op vervaardigingstelsels. Om hierdie argument te steun word 'n analogie getrek tussen the bestuur van leerstelsels en die bestuur van vervaardigingstelsels. Aan die ander kant van die muntstuk word die opvoedkundige aspekte verbonde aan die implementering van ' $n$ leerbestuurstelsel (LMS) aan die Universiteit van Pretoria ondersoek aan die hand van ' $n$ gevallestudie in die Bedryfsingenieursdepartment. Die gevolgtrekking word gemaak dat die bedryfsingenieurs-opleier in ' $n$ unieke posisie is om die opleidingsindustrie te begryp en by dra tot the ontwikkeling daarvan terwyl die bedryfsingenieur opgelei word. 


\section{ENGINEERING THE EDUCATION INDUSTRY: INTRODUCTION}

Corporate and educational institutions alike recognize the potential of e-learning. Gartner predicts that over $60 \%$ of US corporations will have implemented an LMS by the year 2004 [1]. International Data corporation estimates that the corporate spending on e-learning alone will increase from $\$ 1$ bn in 1999 to over $\$ 11$ bn in 2003. In another document by the Gartner Group it is predicted that by $2004,80 \%$ of the leading US and European universities will offer global higher education courses through e-learning [1]. In the same document it is reported that two Southern African universities offered e-learning programmes during 2002. In South Africa alone this number is at least five.

The learner is either the external client of an educational institution [3] or the internal client of corporations that wish to develop their own human resources. In both cases, the learning content is the product and the learning events and assessment events are the primary service [4]. In order to manage these products and services, learning management systems (LMS) and learning content management systems (LCMS) were developed. These systems are not only enablers of paradigm shifts in the educational sector but also often forces behind these changes. These paradigm shifts include the following [3]:

(1) More emphasis is being place on electronic distance education, as well as open and flexible learning environments.

(2) Education is being commercialized and globalised.

(3) Education quality and relevance are pursued more rigorously.

According to the e-learning glossary of Gartner group an LMS is the infrastructure on which e-learning can be built and delivered, whilst LCMSs are used by the learner to customize learning content [5]. Industrial and Systems Engineering skills are equally relevant in the education industry as in the manufacturing industry. To support this argument, an analogy is drawn between the management of learning systems and the management of manufacturing systems:

\section{Manufacturing execution systems compared to learning management systems}

In the manufacturing industry, three levels of systems are generally accepted [6]:

1. The top planning layer comprises systems such as Enterprise Resource Planning (ERP), and Supply Chain Systems (SCS).

2. The Manufacturing Execution System (MES) acts as middleware between the planning and control layers.

3. Control is established through devices and systems such as programmable logic controllers (PLC), supervisory control and data acquisition (SCADA) and manmachine interfaces (MMI).

The ability to execute learning is one of the two criteria used by Aldrich [7] to evaluate current learning management systems. As the name suggests the function an MES is to execute manufacturing. Hence, MES and LMS have the same function (to execute) within different industries. To investigate the correlation between MES and LMS even further, the evolution and core functions of MES and LMS are investigated: 


\section{Evolution of MES}

MES's were developed in the past two decades, whilst LMS's have developed more recently. However, similar paradigm shifts in these industries necessitated these systems. In promoting the need for academic middleware to integrate advanced learning systems, Konstantapoulus highlights paradigm shifts in the education industry that necessitate these systems [8]. These changes correspond with paradigm shifts in the manufacturing industry [9], as shown in Table 1. In both environments, information technology is both a cause and an enabler of change:

\begin{tabular}{|l|l|}
\hline Manufacturing Industry [9] & Education Industry [8] \\
\hline $\begin{array}{l}\text { Mass production strategy was based on the } \\
\text { principle of economies of scale, whilst the new } \\
\text { paradigm, flexible manufacturing, concerns } \\
\text { economies of scope and integration. }\end{array}$ & $\begin{array}{l}\text { Modularisation of the study programme in } \\
\text { order to offer customised qualifications and } \\
\text { enhance student autonomy. Present the } \\
\text { learner with flexibility concerning content, } \\
\text { time, place and mode of communication. }\end{array}$ \\
\hline $\begin{array}{l}\text { Markets, supply chains and collaboration } \\
\text { became global. }\end{array}$ & $\begin{array}{l}\text { Distance learning programs through e- } \\
\text { learning are introduced as part of the regular } \\
\text { studies in an institution. }\end{array}$ \\
\hline $\begin{array}{l}\text { Inter-company programs and collaborative } \\
\text { manufacturing and product development. }\end{array}$ & $\begin{array}{l}\text { Inter-institutional programs have been } \\
\text { developed and collaborative product } \\
\text { development is enabled through information } \\
\text { technology. }\end{array}$ \\
\hline
\end{tabular}

Table 1: Parallel Paradigm shifts: Manufacturing Industry vs. Education Industry

\section{Core functions of an mes and Ims}

McClellan [6] distinguishes between core business functions and support functions in the execution layer. The core functions of an MES are directly associated with the management of production. These functions are listed in the first column of Table 2. Core functions for LMS's and LCMS's are listed by Sinofsky [10] and Lundy [1] respectively. The second column of Table 2 is derived from these lists to show the similarities between the core functions of an LMS and an MES respectively. 


\begin{tabular}{|l|l|}
\hline Core functions of MES [6] & Core Functions of LMS [1],[6] \\
\hline Planning system interface & $\begin{array}{l}\text { External system application programming interfaces, } \\
\text { including human resources and enterprise resource planning } \\
\text { (ERP) systems. The integration of LMS with ERP systems is } \\
\text { one of the most significant current trends concerning business } \\
\text { systems development. [11], [12], [13], [14] }\end{array}$ \\
\hline $\begin{array}{l}\text { Work order and work station } \\
\text { management }\end{array}$ & $\begin{array}{l}\text { Management of curriculum, courses, learning events and } \\
\text { assessment events. Establish student-courseware interface. }\end{array}$ \\
\hline $\begin{array}{l}\text { Inventory tracking and } \\
\text { management and material } \\
\text { movement management }\end{array}$ & $\begin{array}{l}\text { Assigning instructors and course material and managing any } \\
\text { regulatory requirements and history. } \\
\text { Manage skills and records. Build interactivity, work flow and } \\
\text { navigation into the courseware. }\end{array}$ \\
\hline Data collection & $\begin{array}{l}\text { Registration capabilities (curriculum, courses, instructional } \\
\text { responsibilities). }\end{array}$ \\
\hline
\end{tabular}

Table 2: Core Functions: MES vs LMS

The European patent register [15] provides interesting examples of how these functions can be practised:

WO "A learning-assistance system that uses a computer network and that includes a 0175840 server computer that can communicate via the Internet, and student computer terminals that can communicate via a computer network, with said system being such that study-materials data is transmitted from the server computer to one or more student terminals."

GB "An interactive education process permits students at remote locations to provide 2339954 feedback to an instructor in an ordered manner. Inputs are ranked and grouped together. The inquiries and responses are published at an Internet site and are accessible by all the students."

US "The system can also be responsive to an online assessment with remediation and 6301462 guidance. Lessons, implemented by executable software code can be designed to challenge a learner with ever increasing sophisticated levels of encounter and interaction until the learner reaches their limit of knowledge and is forced to acquire additional skills."

US "Computerized training management system: Each task is linked directly to a 5788504 performance objective, which, in turn, is linked directly to a learning objective; then, each enabling objective is linked to its respective test items. In addition, tasks, performance objectives, enabling objectives, and test items are linked to their associated reference documents." 
The South African Qualifications Authority (SAQA) of South Africa [16] (and other qualifications bodies around the world) prescribes that as part of the design of any course, learning outcomes have to be defined. The exit level outcomes for one course may become the entry level outcomes for other courses. Once an appropriate system is in place, customised learning events can be dispatched according to specific learning outcomes achieved.

\section{Support functions of an MES and LMS}

McClellan also lists a number of support functions of MES, including maintenance management, time and attendance, statistical process control, quality assurance, process data/performance analysis, document control/product data management, genealogy/product tractability and supplier management [6]. This list is not a comprehensive list of functions, but rather examples of complementary functions.

Analogically, the following examples of support systems of LMS are given:

In a non-educational corporation, the effects of a specific learning event can be linked to determine the return on investment expected from the particular activity [17]. In terms of new product development, collaborative and even inter-institutional course design and course data management can be established through the appropriate LMS [14].

Karapetrovic [18] shows how statistical quality control (SQC) techniques have been used to measure and improve the quality of education at the Department of Mechanical and Industrial Engineering at the University of Manitoba. The criteria of the Accreditation Board for Engineering and Technology (ABET) are used as "engineering ideal". In the South African context, this accreditation board will be the Engineering Council of South Africa (ECSA). The accreditation standards of this body are set up in accordance with the guidelines from the South African Qualifications Authority (SAQA) [16] and are positioned within the National Qualifications Framework (NQF).

The primary functions of assessment are to rectify (formative assessment) and to qualify (summative assessment). However, the diagnostic value of assessment results is often overlooked. Karapetrovic [18] provides examples of information that can be gathered from assessment data, using statistical process control (SPC) charts:

- Incoming variation in student knowledge concerning how much and how well the students have learned the material.

- "Before" and "after" knowledge can be compared to roughly estimate the value-added outcome.

- "Unnatural effects", such as when a student knew the answer before, but not after, are examined.

- Deterioration in the teacher's presentation of the material.

Anderson-Rowland [19] explains that whilst qualitative data, including anecdotes, can be useful in evaluating a learning program, decision makers on the future of a program usually want quantitative evidence that the program made a difference. Both formative and summative evaluation needs to be planned before a program commences so that the proper data can be obtained. It is especially important to have baseline data so that the results due to 
a program can be compared with the situation before the program took effect. Before and after data need to be identified carefully so the comparison of the program effect with the preprogram situation can be made on the same person.

Theoretically an LMS could provide the same support to the learning process than an MES provide to the manufacturing process, through the applications discussed in this section. However, not all LMS's provide this support. In the remainder of this article, it is shown how an LMS is used to accomplish flexible learning.

\section{EDUCATING THE INDUSTRIAL ENGINEER: INTRODUCTION}

As part of its Education Innovation initiative the University of Pretoria is in the process of introducing WebCT (World Wide Web Courseware Tools [21]) as LMS for most of its courses. In 2001 WebCT was implemented as LMS for the Productivity 220 course presented to undergraduate Industrial Engineering students at the University of Pretoria. This is a second-semester course in the undergraduate program in Industrial Engineering and was traditionally presented through formal lectures and practical sessions. Brown [3] compiled a matrix according to which the technology content of the learning environment and the learner need can be classified (Figure 1).

The typical Productivity 220 course learning environment fits in quadrant A of this figure. (Lecturer-controlled environment with no information technology).

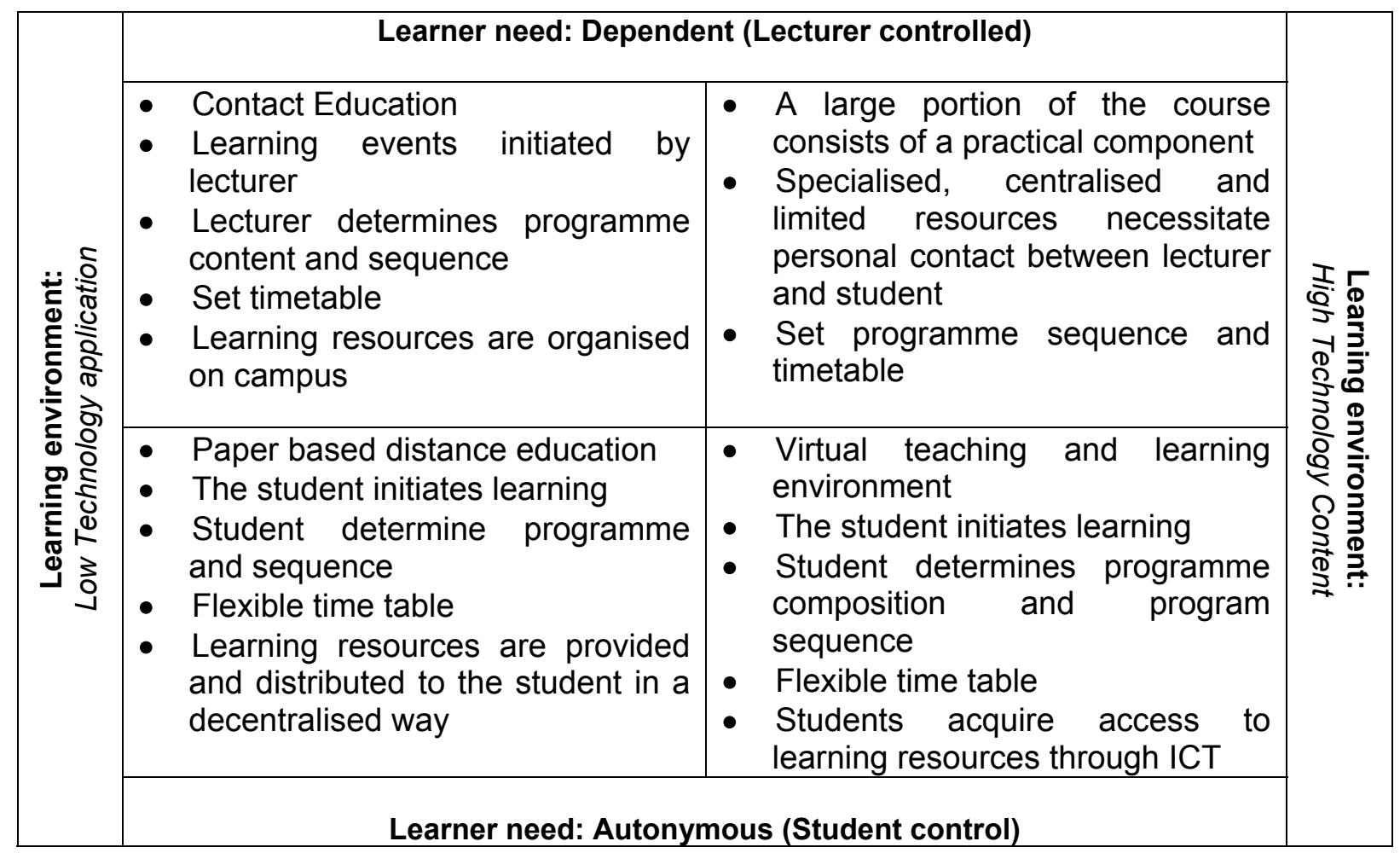

Figure 1: Learner need compared to technology in environment 
The typical student who chooses to function in an A-quadrant environment needs strong guidance, he relies on tutors and lecturers, prefers a preset timetable and does not want to take responsibility for learning events [3]. These students function according to the old education paradigm, since their ability to realize their own educational efforts is ignored [22]. The average second-year Industrial Engineering student at the University of Pretoria shares the following characteristics with the learner who prefers to function in the A quadrant:

1. Inexperienced as a student in higher education. The need for "student life" social interaction exists: The average second year Industrial Engineering student is 20.5 years old and is enrolled for the second year of their first degree.

2. Residential study: The average second year Industrial Engineering student resides $4.3 \mathrm{~km}$ from campus (maximum $=17 \mathrm{~km}$ ).

However, whilst the typical A quadrant student is unfamiliar with the use of information technology, the undergraduate Industrial Engineering student has completed the first-year Engineering Computer Competency course (CIL110). Furthermore, 87 per cent (182 out of 209) of the undergraduate Industrial Engineering students added an e-mail address to their contact details, which may imply that they feel comfortable with Internet technology. (The records of 2691 other non-engineering undergraduate students were consulted to conclude that only 62,8 per cent of these students use e-mail). WebCT can be used as LMS to establish a shift from a lecturer-controlled environment (quadrant A of Figure 1) to a flexible, studentcontrolled learning environment (quadrant C of Figure 1) in the Department of Industrial and Systems Engineering.

In the context of IT-enabled learning environments, Collis identified five modes of flexibility as priorities for combining principles of good teaching and learning with the needs of increasingly diverse student cohorts [23]:

(1) Flexibility of time and location

(2) Flexibility in types of communication and (3) interactions

(4) Flexibility in programme and (5) study materials

\section{Flexibility in interactions}

Figure 2 shows how flexibility of time and location was introduced through WebCT. In terms of the policy of the school of engineering, an undergraduate student should spend $50 \%$ of all notional time in the presence of the facilitator, normally at a fixed lecturer-controlled location. This is called contact time. The other $50 \%$ is non-contact time, therefore the student is learning at a location of his choice, without the presence of the lecturer. This traditional situation is represented by Figure $2 \mathrm{a}$.

During the first semester of 2001, WebCT was used on an experimental basis for the Productivity 220 course ( Figure $2 \mathrm{~b}$ ). One out of four contact sessions per week $(12.5 \%$ of total notional hours) was spent in the computer laboratory, using WebCT. Students spent $10 \%$ of the non-contact time, using WebCT to extract information and complete homework assignments, as indicated by the black line on Figure 2 . 
A student survey at the end of the first semester revealed that students would prefer to use WebCT even more for non-contact time information extraction and homework assignments, as well as instruction during contact time. These suggestions were implemented during the second semester of 2001 ( Figure 2c).

Figure $2 \mathrm{~d}$ represents the average time allocation reflected by nineteen WebCT facilitators interviewed at the University of Pretoria. Traditional contact time is reduced and flexibility of time and location is increased when a WebCT learning environment is introduced. The skewness of this figure towards non-contact time may be attributed to the fact that postgraduate courses (which consists normally of fewer contact hours) take precedence when WebCT is introduced. Whether contact or non-contact teaching is considered, WebCT influences flexibility in terms of communication.

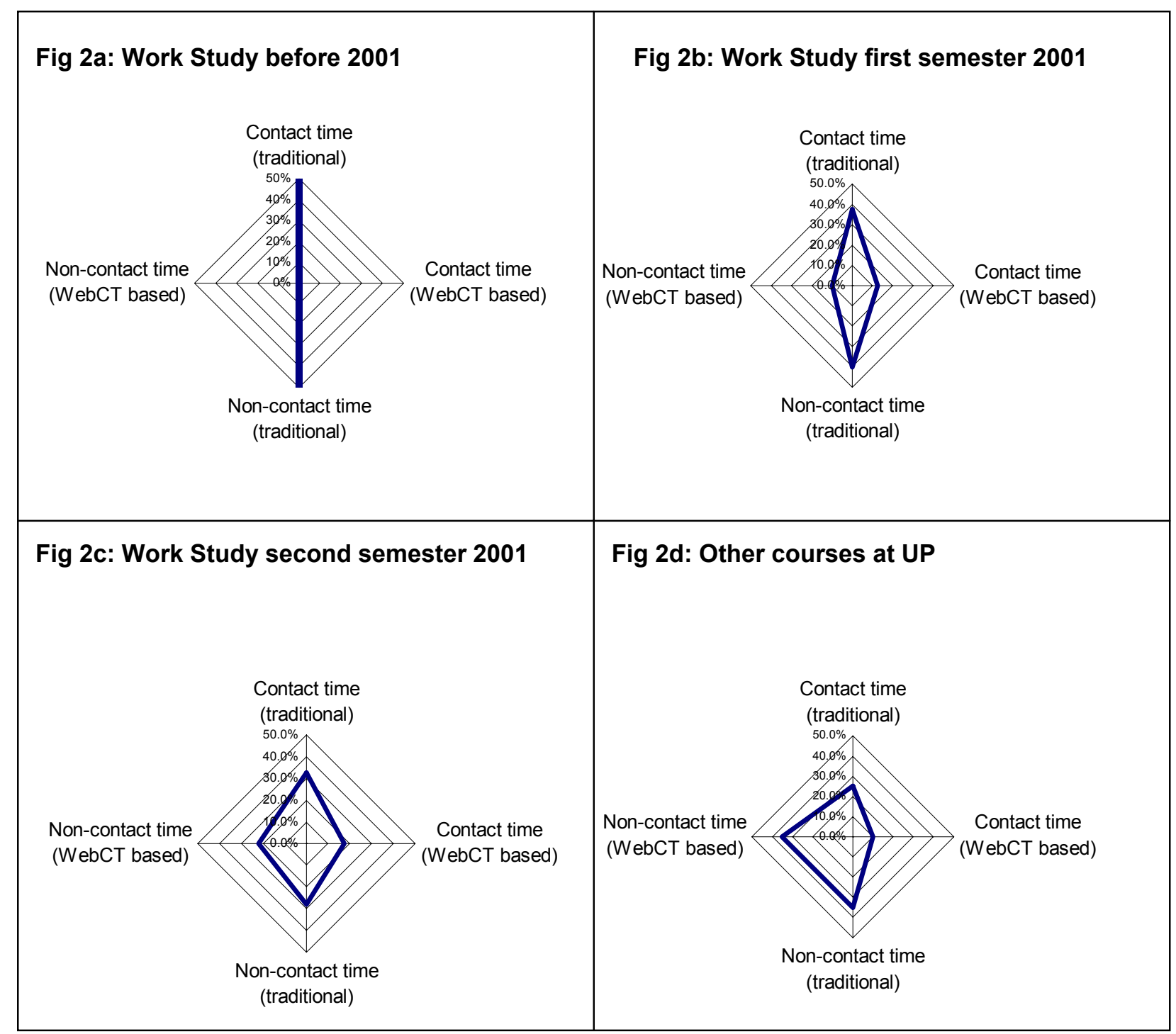

Figure 2: Flexibility in time and location through WebCT 


\section{Flexibility in communications}

Collis [23] solely refers to communication with the facilitator ("instructor"), when she discusses the need for flexibility in forms of communication. The communication between the learner and the facilitator is modeled in Figure 3 [22].

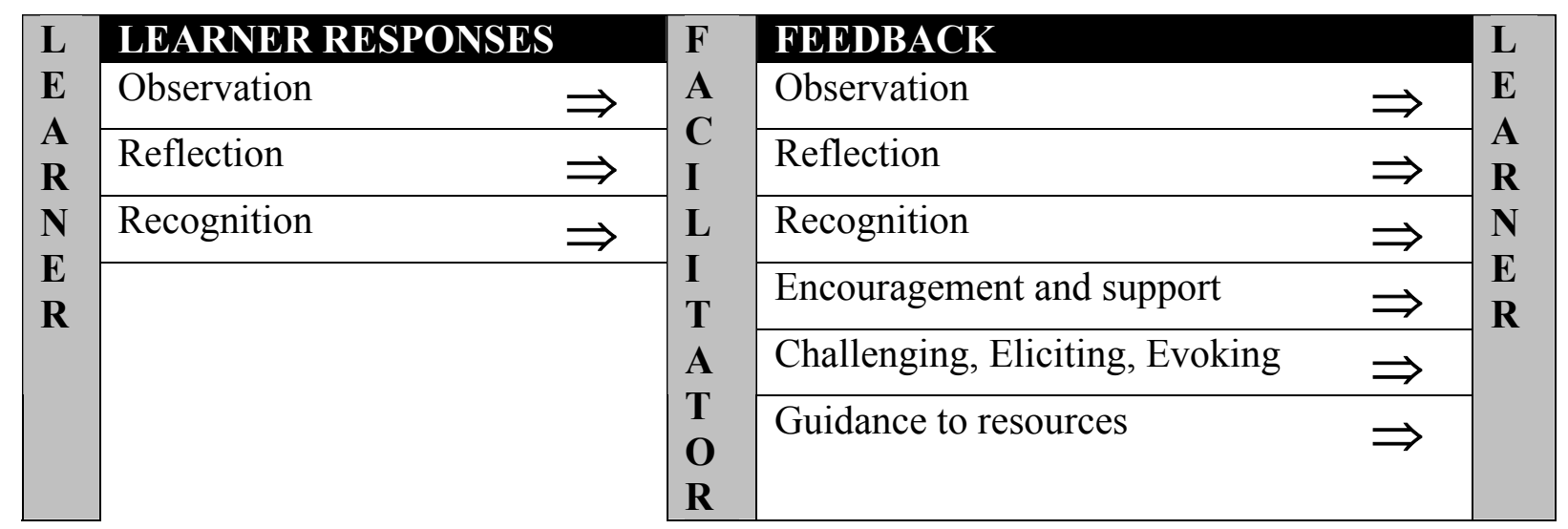

Figure 3: Learner responses and feedback

Both the learner responses and the facilitator's feedback are subsequently discussed in more detail:

\section{- Observing, reflecting upon and recognizing learner response}

A drawback of communication through WebCT is that valuable non-verbal signs cannot be transferred. Hence, the decrease in personal interaction is identified as one of the greatest threats of computer-controlled learning environments. Interviews with seventeen WebCT facilitators at the University of Pretoria revealed that although the average contact time had been reduced through WebCT, none of respondents found it feasible to eliminate contact time completely.

On the other hand, some sense of security is provided through electronic communication. Eight percent of Industrial Engineering students surveyed indicated that they prefer to communicate with the lecturer through e-mail, since they can express themselves better and have more confidence to ask questions by means of e-mail. To provide flexibility in communication, students should have the facility to choose a communication mode most appropriate to their specific need. Therefore, whilst the WebCT e-mail and discussion tool could be exploited even more, it should not replace face-to-face communication.

\section{- Provide feedback on learner response}

Due to the lack of non-verbal communication, facilitators' responses through observation, recognition and direct affective encouragement are less efficient. Feedback has both a motivational (reinforcement) and an informative (training and remedial) value [27]. The electronic feedback on quizzes reduces the workload of the facilitator, but the personal motivation (reinforcement) is reduced. However, through WebCT, the lecturer can give 
personal feedback to quiz answers from individual students. Three quarters $(73 \%)$ of the Industrial Engineering students surveyed read the individual feedback on quizzes, $38 \%$ of these always found the feedback valuable. Of the $27 \%$ of students who did not read the feedback, $21 \%$ were unaware of this facility.

By means of the electronic discussion groups, the facilitator can paraphrase his interpretation or add a challenging comment/question in reply to a student's public posting. The facilitator can even disguise himself as a student to authenticate this challenge. This dialogue is accessible to all students. Guidance to resources can be provided accordingly, without duplicating information. In this way, WebCT contributes towards reflection (paraphrasing), challenging, eliciting and evoking, as well as guidance to resources as feedback

\section{FLEXIBILITY IN PROGRAM AND STUDY MATERIALS}

The undergraduate Industrial Engineering students regarded the opportunity to schedule applicable learning events according to their own flexible timetable as the single greatest advantage of the learning environment. The WebCT version currently used at the University of Pretoria does not enable calendar integration between different courses. If the calendar of all courses can be integrated, the schedules of physical and human resources could be managed accordingly. Additional control measures need to be implemented to enable the tracking of these resources. In each separate course, the scheduling of learning events, the compilation of learning groups according to certain criteria and the allocation of teaching assistants and learning material can be managed through WebCT.

The automatic dispatch of learning, given certain prerequisites, is an enabler of flexible learning and one of the greatest advantages of ICT for learning environments. As with other terminologies in the education sector, the term Just-In-Time (JIT) is borrowed from the manufacturing sector to describe the action of making available the most up-to-date learning event just in time for the learning experience [24].

Learnframe [25] proposes an LMS that dispatches learning material and learning events as follows: As students progress, information is delivered based on what was learned and how the students performed. For example, a student would log onto the learning server and a customized course would be generated from the content database recognising the courses the learner took, how well he did, what his job description was, what problem was most pressing. WebCT lacks the sophistication required to execute the dispatch of learning material as explained above. However, for the Productivity 220 course, students were allowed access to additional material according to their performance in previous electronic tests.

A number of students expressed the need for links to more study material and case studies, related directly or indirectly to the course. Wallace found that the WWW provides new opportunities for students to play a more active role in the acquisition of knowledge [28]. For the Productivity 220 course, students share the responsibility of identifying appropriate additional resources for the course, as recommended by Collis [23].

These resources are shared with peer students by means of the presentation tool of WebCT. A wider selection of resources and modalities of study materials can be distributed through 
WebCT. These include video clips and relevant computer applications. Exploitation of this WebCT facility is identified as one of the opportunities for the WebCT classroom.

\section{CONCLUSION}

"It has long been known that industrial engineers have the technical training to make improvements in a manufacturing setting. Now it is increasingly being recognized that these same techniques can be used to evaluate and improve productivity and quality in service industries." [26]

As a result of the information revolution, e-learning, learning management systems and learning content management systems currently receive considerable attention from both systems engineers and educators. In this regard, the Industrial Engineering educator is in the unique position of understanding and contributing towards the engineering of the education industry whilst educating the industrial engineer.

\section{REFERENCES}

[1] Lundy, J., Harris, K., E-learning Suites Emerge: Prices Down, Functionality up, Gartner Research Note, M-13-6236, 18 June 2001.

[2] Lundy J., Logan, D., Renaissance and Reality - What the Telecoms Buildout Takes, Connect-World Africa, http://www.connect-world.com, Issue 1, 2002

[3] Brown, T.H., 1999, Focussing on the client - Into the future with flexible learning,Discussion document of the department of Telematic Education, http://www.up.ac.za/telematic/intranet/intranet.htm, University of Pretoria.

[4] Patel, N.V., "Application of soft systems methodology to the real world process of teaching and learning", International Journal of Educational Management, Vol. 9, No. 1, 1995,pp.13-23@MCB University Press, 0951-354X.

[5] Lundy, J., Harris, K., Igou, B., Zastrocky, M., "Gartner's E-Learning Glossary”, Gartner Research Note, M-14-9025, 7 January 2002.

[6] McClellan, M., (1997), Applying MES, St. Lucie Press, USA.

[7] Aldrich, C., Learning Management Systems: The 2000 Magic Quadrant, Gartner Commentary, COM-11-6673, 11 August 2000.

[8] Konstantopoulus, M., Spyrou, T., Darzentas, J., (2001) "The need for academic middleware to support advanced learning services", Computer networks, Vol. 37 (2001), pp. 773-781, Elsevier.

[9] Duguay, C.R., Landry, S., Pasin, F., (1997) "From mass production to flexible/ agile manufacturing", International Journal of Operations \& Production Management, Vol. 17, No. 12, 1997, pp. 1183-1195 @ MCB University Press, 0144-3577.

[10] Sinofsky, J., (2001), "Integrating your Learning Management System With your ERP system” THINQ White Paper, C 2001, THINQ Learning Solutions Inc., http://learning.thinq.com/press/whitepapers.htm

[11] Iyer, V., "E-learning is the future of Knowledge Management", NASSCOM Gartner Summit 2002, 29 September 2002, http://www.zdnetindia.com, [23 April 2003].

[12] IBM, "IBM unveild next generation Learning Management System and Lotusphere 2003", IBM website, http://www.ibm.com/news/2003/01/272.html, [2 March 2003].

[13] Hall, J., “Assessing Learning Management Systems”, Chief Learning Officer, January 2003, http://www.clomedia.com, [23 April 2003]. 
[14] Hall, B., (2001) Learning Management Systems: How to Choose the Right System for Your Organization, www.brandon-hall.com, 690 W. Fremont Ave., Suite 10, Sunnyvale.

[15] European network of patents databases (2001) http://ep.espacenet.com/

[16] SAQA, (2002), South African Qualifications Authority, http://www.saqa.org.za

[17] Learnframe, (2000), Facts, Figures \& Forces Behind e-learning, compiled by Learnframe, August 2000, http://www.learnframe.com/aboutelearning

[18] Karpatrovic, S., Rajamani, D., (1998), An Approach to the Application of Statistical Quality Control Techniques in Engineering Courses, Journal of Engineering Education, July 1998.

[19] Anderson-Rowland, M.R., Statistics for Program Assessment: Has the Program Made a Difference?, Proceedings of the annual conference of the American Society for Engineering Education, Montreal, Canada, June 2002.

[20] Rhoads, T.R., Chimka, J.R., Moore, M., Balanced Scorecard for Education Assessment, Proceedings of the annual conference of the American Society for Engineering Education, Montreal, Canada, June 2002.

[21] WebCT, World Wide Web Courseware tools homepage, http://www.webct.com, 2002.

[22] Slabbert, J.A., (1997), A Quantum Leap to Excellence, University of Pretoria.

[23] Collis, B., (1998) New Didactics for university instruction: why and how?, Computers \& Education, Vol 31, Issue 4, pp. 373-393.

[24] Ellis, R.K., (2001), "LCMS Roundup", Learning Circuits, http://www.learningcircuits.org/2001/aug2001/ttools.html.

[25] Learnframe, Facts, Figures \& Forces Behind e-learing, compiled by Learnframe, August 2002, http://www.learnframe.com/aboutlearning.

[26] Institute of Industrial Engineers, (2002) "Learn about IE", http://www.iienet.org/.

[27] Moller, J.J., (1997) Guidelines for designing and developing computer assisted instructional programmes, In: Successful teaching: guidelines for lecturers, teachers and trainers, Malan, S.P.T., Du Toit, P.H., and Van Oostrum, L.J., Bureau for Academic Support Services: University of Pretoria.

[28] Wallace, D.R., Weiner, S.T., (1998), How Might Classroom Time be Used Given WWW-Based Lecturers, Journal of Engineering Education, July 1998. 